\title{
Deferasirox Decreases Liver Iron Concentration in Iron-Overloaded Patients with Myelodysplastic Syndromes, Aplastic Anemia and Other Rare Anemias
}

\author{
Yutaka Kohgo $^{a} \quad$ Akio Urabe $^{b}$ Yurdanur Kilinç $^{d}$ Leyla Agaoglu ${ }^{\mathrm{e}}$ \\ Krzysztof Warzocha ${ }^{f}$ Koichi Miyamurac ${ }^{c}$ Lay Cheng Lim ${ }^{\text {h }}$ Sabine Glaser $^{\mathrm{i}}$ \\ Candace Wang ${ }^{j}$ Wieslaw Wiktor-Jedrzejczak ${ }^{g}$

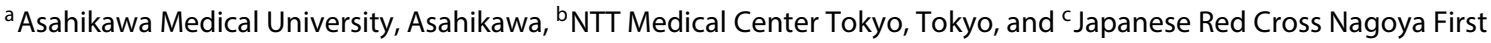
Hospital, Nagoya, Japan; ${ }^{\mathrm{d} C ̧ u k u r o v a}$ University Medical Facility, Adana, and ${ }^{\mathrm{e}}$ Istanbul University, Istanbul Medical Faculty, Istanbul, Turkey; ${ }^{\mathrm{f}}$ Institute of Hematology and Blood Transfusion Medicine, and ${ }^{9}$ The Medical University of Warsaw, Warsaw, Poland; ' $S$ Singapore General Hospital, Singapore, Singapore; 'Novartis Pharma AG, Basel, Switzerland; jNovartis Pharmaceuticals, East Hanover, N.J., USA
\end{abstract}

For editorial comment see p. 231

\author{
Key Words \\ Deferasirox · Myelodysplastic syndromes - Aplastic anemia • \\ Chelation · Iron
}

\begin{abstract}
Iron overload in transfusion-dependent patients with rare anemias can be managed with chelation therapy. This study evaluated deferasirox efficacy and safety in patients with myelodysplastic syndromes (MDS), aplastic anemia (AA) or other rare anemias. A 1-year, open-label, multicenter, singlearm, phase II trial was performed with deferasirox (10-40 $\mathrm{mg} / \mathrm{kg} /$ day, based on transfusion frequency and therapeutic goals), including an optional 1-year extension. The primary end point was a change in liver iron concentration (LIC) after 1 year. Secondary end points included changes in efficacy and safety parameters (including ophthalmologic assessments) overall as well as in a Japanese subpopulation. Overall, 102 patients ( 42 with MDS, 29 with AA and 31 with other rare anemias) were enrolled; 57 continued into the extension. Mean absolute change in LIC was $-10.9 \mathrm{mg} \mathrm{Fe} / \mathrm{g}$ dry weight (d.w.) after 1 year (baseline: $24.5 \mathrm{mg} \mathrm{Fe} / \mathrm{g} \mathrm{d.w.)}$ and $-13.5 \mathrm{mg} \mathrm{Fe} / \mathrm{g}$ d.w. after 2 years. The most common drugrelated adverse event was increased serum creatinine
\end{abstract}

(23.5\%), predominantly in MDS patients. Four patients had suspected drug-related ophthalmologic abnormalities. Outcomes in Japanese patients were generally consistent with the overall population. Results confirm deferasirox efficacy in patients with rare anemias, including a Japanese subpopulation. The safety profile was consistent with previous studies and ophthalmologic parameters generally agreed with baseline values (EUDRACT 2006-003337-32).

(C) 2015 S. Karger AG, Basel

\section{Introduction}

Reliance on red blood cell (RBC) transfusion is common among patients with rare anemias. Regular transfusion is needed in $>30 \%$ of patients with Diamond-Blackfan anemia [1], in up to $90 \%$ of those with myelodysplastic syndromes (MDS) [2] and is also an essential component of treatment for aplastic anemia (AA) [3]. In such patients, secondary iron overload may result in tissue damage and organ failure, and is negatively associated with survival [3-7]. These data underline the importance of appropriate patient management, including adequate iron chelation [8-12].

\begin{tabular}{ll}
\hline KARGER 125\% & $\begin{array}{l}\text { (1) 2015 S. Karger AG, Basel } \\
0001-5792 / 15 / 1344-0233 \$ 39.50 / 0 \quad \text { Karger }\end{array}$ \\
$\begin{array}{l}\text { E-Mail karger@karger.com } \\
\text { www.karger.com/aha }\end{array}$ & $\begin{array}{l}\text { This is an Open Access article licensed under the terms of the } \\
\text { Creative Commons Attribution-NonCommercial 3.0 Un- } \\
\text { ported license (CC BY-NC) (www.karger.com/OA-license), } \\
\text { applicable to the online version of the article only. Distribu- } \\
\text { tion permitted for non-commercial purposes only. }\end{array}$
\end{tabular}

Yutaka Kohgo, $\mathrm{MD}, \mathrm{PhD}$

Division of Gastroenterology and Hematology/Oncology

Department of Medicine, Asahikawa Medical College

Midorigaoka-higashi 2-1, Asahikawa 078-8510 (Japan)

E-Mail yk1950@asahikawa-med.ac.jp 
The efficacy and safety of once-daily deferasirox treatment in reducing or maintaining body iron has been demonstrated in several studies involving large numbers of patients with a variety of transfusion-dependent anemias [13-19] including subpopulations of patients with rare anemias, such as MDS and AA [13, 15, 20-27]. However, studies evaluating oral iron chelation therapy among Japanese patients, in particular, are lacking. Epidemiological surveys of iron-overloaded Japanese patients, most of whom had MDS or AA, have revealed that administering deferoxamine in an outpatient setting can be a barrier to optimal chelation outcomes $[28,29]$. Furthermore, mortality rates were higher among patients with increased serum ferritin levels ( $\geq 1,000$ vs. $<1,000 \mathrm{ng} / \mathrm{ml}$ ), with liver and cardiac dysfunction being the primary cause of death. Data on the efficacy of deferasirox in a large population of Japanese patients would thus be of clinical benefit.

The aim of this study was to evaluate the efficacy and safety of deferasirox, dosed according to transfusional iron intake and therapeutic goal, in patients with transfusionrelated iron overload associated with anemias other than $\beta$-thalassemia or sickle-cell disease. Assessment of the deferasirox safety profile included specific analysis of hepatic, renal and ophthalmologic parameters; notable abnormalities related to these areas have already been identified [30]. In addition, the study aimed to evaluate the efficacy of deferasirox in a large subpopulation of Japanese patients.

\section{Patients and Methods}

\section{Patients}

Enrolled patients were male or female patients aged $\geq 2$ years with transfusional iron overload due to low/intermediate-risk MDS (Int-1, as determined by the International Prognostic Scoring System), AA or other congenital or acquired anemias (including Diamond-Blackfan anemia, myelofibrosis or specific enzyme deficiency, but excluding $\beta$-thalassemia and sickle-cell disease). A lifetime transfusion history of $\geq 20$ units (approx. $100 \mathrm{ml} / \mathrm{kg}$ ) of packed $\mathrm{RBC}$ or serum ferritin $>1,000 \mathrm{ng} / \mathrm{ml}$ was also required. Exclusion criteria included serum creatinine above the upper limit of normal (ULN), alanine aminotransferase levels $>5$ times ULN, a urinary protein/creatinine ratio $>0.5 \mathrm{mg} / \mathrm{mg}$ and a history of human immunodeficiency virus or hepatitis B or C. The study was conducted in accordance with Good Clinical Practice guidelines and the Declaration of Helsinki. It was approved by the relevant independent ethics committee or institutional review board at each site. Informed consent during screening and before enrolling into the extension phase was obtained.

Study Design

This phase II study CICL670A2204 (EUDRACT 2006-00333732) was an open-label, multicenter, single-arm study to assess the efficacy and safety of deferasirox in patients with MDS, AA and other rare anemias. It was a 1-year trial, with an option of continuing into the extension phase, if the investigator deemed that continued chelation was required based on liver iron concentration (LIC) assessment by magnetic resonance imaging (MRI).

The initial recommended dose was $20 \mathrm{mg} / \mathrm{kg} /$ day. For patients receiving more frequent transfusions, i.e. $>14 \mathrm{ml} / \mathrm{kg} / \mathrm{month}$ defined as $>4$ units ( $200 \mathrm{ml} /$ unit) packed $\mathrm{RBC} /$ month, $30 \mathrm{mg} / \mathrm{kg} /$ day was recommended. For patients receiving less frequent transfusions, i.e. $<7 \mathrm{ml} / \mathrm{kg} / \mathrm{month}$ defined as $<2$ units ( $200 \mathrm{ml} /$ unit) packed $\mathrm{RBC} / \mathrm{month}, 10 \mathrm{mg} / \mathrm{kg} /$ day was recommended. The maximum dose allowed was $40 \mathrm{mg} / \mathrm{kg} /$ day. Dose adjustments were made based on therapeutic response to the drug and continuous assessment of safety markers including serum creatinine, serum aminotransferase or the development of a skin rash.

The primary efficacy end point was the absolute change in LIC from baseline to the end of year 1 . Secondary end points included an absolute change in LIC after 2 years, a change in serum ferritin after 1 and 2 years, changes in LIC and serum ferritin in Japanese patients and safety and tolerability parameters (including ophthalmologic changes) in both Japanese and non-Japanese patients.

\section{Assessments}

A validated R2-MRI (FerriScan ${ }^{\circledR}$ ) technique [31] was used to assess the absolute change in LIC from baseline at the end of year 1 and year 2. Serum ferritin was evaluated at a central laboratory at baseline and then monthly throughout the study.

Safety was evaluated through continuous monitoring and recording adverse events (AEs), serious AEs (SAEs) and monthly evaluation of liver and renal parameters. Ophthalmologic parameters, including visual acuity, tonometry and photography of the retina and optic nerve, were assessed at 6-monthly intervals.

\section{Statistical Methods}

A 95\% confidence interval (CI) for the mean absolute change in LIC was calculated based on the normal distribution. This corresponded to a hypothesis test with a 1-sided significance level of $\alpha=0.025$. Efficacy was assessed in a per-protocol set 1 analysis (PP1) which included all patients with LIC assessments at baseline and after 1 year, and in a per-protocol set 2 analysis (PP2) which included patients with LIC values at baseline and at the end of 2 years. Sensitivity analyses were performed for both the 1-year and 2-year analyses based on the safety set. For patients who withdrew from the study prior to the year 1 LIC measurement, the sensitivity analyses used the last observation for the year 1 time point. The safety set consisted of all patients who received at least one dose of study drug.

\section{Results}

\section{Patient Disposition and Baseline Demographics and}

\section{Characteristics}

The study was conducted between October 2007 and February 2012 in 31 centers across five countries (Japan, Poland, Singapore, Spain and Turkey). In total, 102 patients were enrolled (fig. 1), 68 of whom (66.7\%) completed 1 year of the study. Overall, 57/102 patients (55.9\%) continued into the extension phase, 52 of whom (91.2\%) 


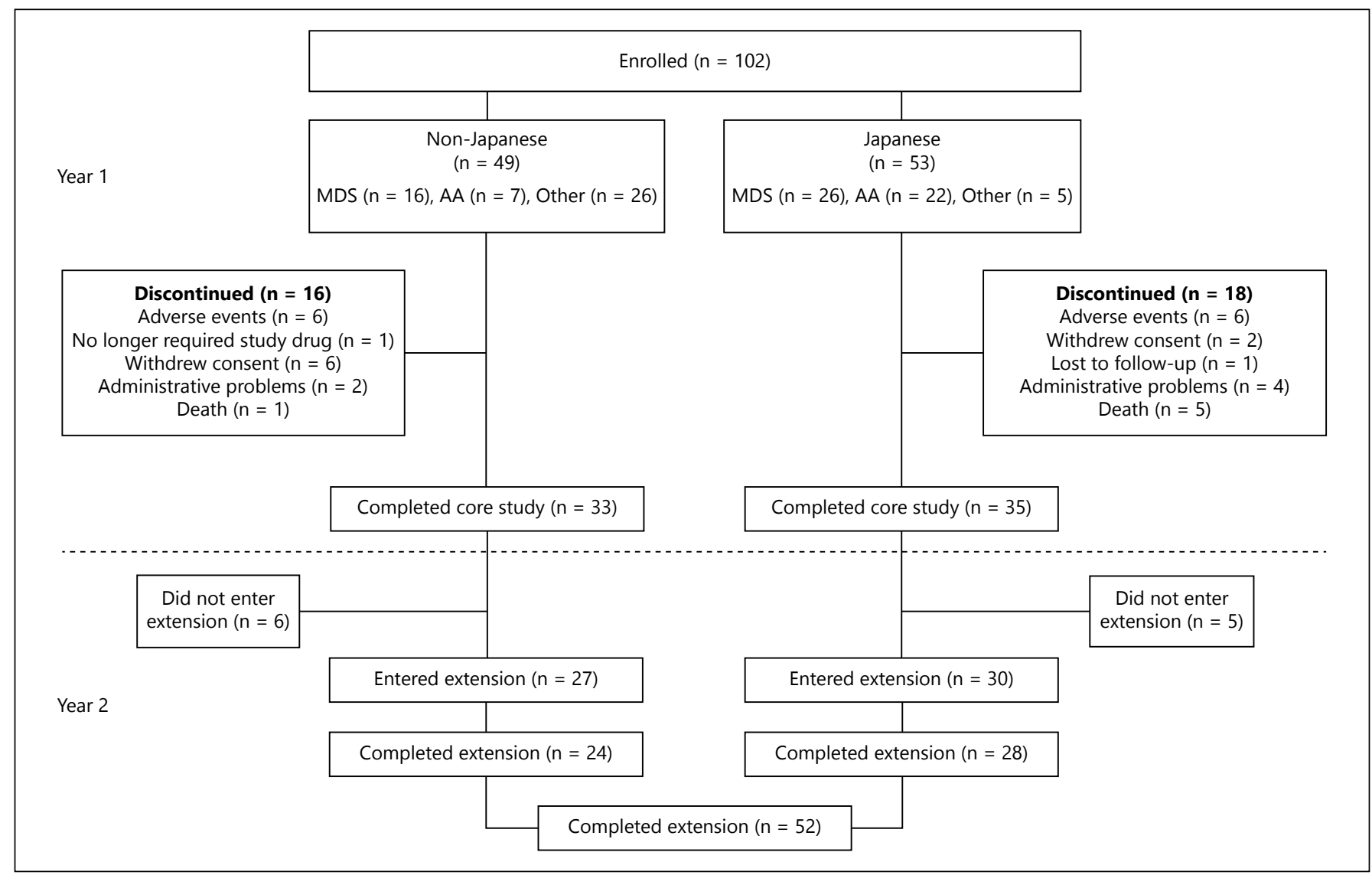

Fig. 1. Patient disposition.

completed 2 years of deferasirox treatment. Overall, 56 (54.9\%) patients were Asian, including 53 patients from Japan (table 1). However, 22 and 27 Japanese patients as well as 30 and 34 non-Japanese patients were excluded from PP1 and PP2, respectively; this was as a result of missing data (patients did not fulfill the criteria of having an MRI LIC assessment at both baseline and at the end of year 1 or year 2 within the required time windows). There were no differences in discontinuations, either in patients with different ethnicities (Japanese and non-Japanese) or in patients with different anemias. Over half of the patients had LIC $\geq 15 \mathrm{mg} \mathrm{Fe} / \mathrm{g}$ dry weight (d.w.), with differences in baseline LIC and serum ferritin from underlying anemia (table 1). Overall, baseline LIC and serum ferritin values were lowest for patients with other rare anemias and highest in patients with AA.

\section{Deferasirox Dosing and Exposure}

The mean \pm standard deviation (SD) actual deferasirox dose was $17.8 \pm 6.4 \mathrm{mg} / \mathrm{kg} /$ day $(17.4 \pm 5.4,15.2 \pm 5.3$ and $20.6 \pm 7.6 \mathrm{mg} / \mathrm{kg} / \mathrm{day}$ for MDS, AA and other rare anemias, respectively) with an overall median exposure to deferasirox of 90.5 weeks (range 1-119 weeks) for the 102 enrolled patients. Exposure was 94.4 weeks for MDS patients, 52.0 weeks for AA patients and 102.9 weeks for patients with other rare anemias.

Use of concomitant medications and significant nondrug therapies were reported in 97 (95.1\%) patients overall. Concomitant macrolide and antibiotic use were generally comparable among the underlying anemias. Ophthalmologic preparation of the calcineurin inhibitor, cyclosporine, was most frequently used concomitantly in patients with AA ( $\mathrm{n}=13,44.8 \%)$.

Dose adjustments and interruptions were required in 90 patients $(88.2 \%)$. Patients with other rare anemias had more of these than patients with MDS and AA, with the median duration of interruption (21.5 days) being 2 -fold higher than in MDS and AA patients. The most frequent cause for dose adjustments and/or interruptions was an AE, both overall $(\mathrm{n}=71,69.6 \%)$ and within each patient group [MDS: $\mathrm{n}=33(78.6 \%), \mathrm{AA}: \mathrm{n}=23(79.3 \%)$ and other rare anemias: $\mathrm{n}=15(48.4 \%)]$. The most common AEs 
Table 1. Patient demographics and baseline characteristics

\begin{tabular}{|c|c|c|c|c|}
\hline Baseline characteristic & $\operatorname{MDS}(\mathrm{n}=42)$ & $\mathrm{AA}(\mathrm{n}=29)$ & Other rare anemias ${ }^{\mathrm{a}}(\mathrm{n}=31)$ & All patients $(n=102)$ \\
\hline \multicolumn{5}{|l|}{ Age, years } \\
\hline Mean \pm SD & $63.6 \pm 15.9$ & $48.9 \pm 21.1$ & $25.4 \pm 25.1$ & $47.8 \pm 25.9$ \\
\hline Median (range) & $67.0(11.0-82.0)$ & $53.0(4.0-77.0)$ & $13.0(2.0$ to 85.0$)$ & $56.5(2.0-85.0)$ \\
\hline Male:female, $\mathrm{n}$ & $19: 23$ & $17: 12$ & $17: 14$ & $53: 49$ \\
\hline \multicolumn{5}{|l|}{ Race } \\
\hline Caucasian & $14(33.3)$ & $7(24.1)$ & $25(80.6)$ & $46(45.1)$ \\
\hline Asian & $28(66.7)$ & $22(75.9)$ & $6(19.4)$ & $56(54.9)$ \\
\hline \multicolumn{5}{|l|}{ Ethnicity } \\
\hline Japanese & $26(61.9)$ & $22(75.9)$ & $5(16.1)$ & $53(52.0)$ \\
\hline Other & $11(26.2)$ & $7(24.1)$ & $25(80.6)$ & $43(42.2)$ \\
\hline Hispanic/Latino & $4(9.5)$ & 0 & 0 & $4(3.9)$ \\
\hline Chinese & $1(2.4)$ & 0 & $1(3.2)$ & $2(2.0)$ \\
\hline \multicolumn{5}{|l|}{ LIC, mg Fe/g d.w. } \\
\hline Mean \pm SD & $25.4 \pm 16.5$ & $27.7 \pm 15.8$ & $20.0 \pm 13.4$ & $24.5 \pm 15.6$ \\
\hline \multicolumn{5}{|l|}{ Categories } \\
\hline$<7$ & $2(4.8)$ & $2(6.9)$ & $3(9.7)$ & $7(6.9)$ \\
\hline$\geq 7$ to $<15$ & $12(28.6)$ & $4(13.8)$ & $8(25.8)$ & $24(23.5)$ \\
\hline$\geq 15$ & $24(57.1)$ & $20(69.0)$ & $14(45.2)$ & $58(56.9)$ \\
\hline Missing & $4(9.5)$ & $3(10.3)$ & $6(19.4)$ & $13(12.7)$ \\
\hline \multicolumn{5}{|l|}{ Serum ferritin, $\mathrm{ng} / \mathrm{ml}$} \\
\hline Median (range) & $3,006(538-12,360)$ & $3,450(1,389-27,550)$ & $2,646(110-8,687)$ & $2,999(110-27,550)$ \\
\hline \multicolumn{5}{|l|}{ Categories } \\
\hline$<1,000$ & $1(2.4)$ & 0 & $4(12.9)$ & $5(4.9)$ \\
\hline 1,000 to $<2,500$ & $16(38.1)$ & $9(31.0)$ & $11(35.5)$ & $36(35.3)$ \\
\hline 2,500 to $<5,000$ & $16(38.1)$ & $11(37.9)$ & $9(29.0)$ & $36(35.3)$ \\
\hline$>5,000$ & $9(21.4)$ & $9(31.0)$ & $7(22.6)$ & $25(24.5)$ \\
\hline
\end{tabular}

Values denote $\mathrm{n}(\%)$, unless otherwise indicated.

a Including congenital hemolytic anemia, pure red-cell aplasia, Diamond-Blackfan anemia, congenital erythropoietic porphyria, hypoplasia (medulla ossium), chronic myeloproliferative disease, myelofibrosis, congenital dyserythropoietic anemia, $\alpha$-thalassemia, hereditary spherocytosis and Fanconi's anemia.

requiring dose adjustment or interruption were increased serum creatinine in 19 (18.6\%) patients (MDS: 23.8\%, AA: $24.1 \%$ and other rare anemias: $6.5 \%$ ) and renal impairment in $9(8.8 \%)$ patients (MDS: $7.1 \%$, AA: $17.2 \%$ and other rare anemias: $3.2 \%$ ). Overall, $13.7 \%$ of patients experienced an $\mathrm{AE}$ that led to discontinuation of the study drug, with pyrexia (2\%) and hypersensitivity (2\%) being the most frequent (i.e. in $\geq 2$ patients).

\section{Efficacy of Deferasirox}

Changes in Liver Iron Concentration

At the end of year 1 for the 50 patients evaluated (PP1), the mean absolute change in LIC was $-10.9 \pm 11.9 \mathrm{mg}$ Fe/g d.w. (95\% CI -14.3 to $-7.5 ; \mathrm{p}<0.001$; fig. 2a). The overall mean relative change in LIC was $-42.9 \%$. Similar results were seen for each underlying anemia, with a slightly greater decrease in patients with AA. Absolute changes in LIC were $-10.1 \pm 13.3$ (95\% CI -16.0 to -4.2 ),
$-13.1 \pm 13.6(95 \% \mathrm{CI}-22.3$ to -4.0$)$ and $-10.6 \pm 8.9 \mathrm{mg}$ $\mathrm{Fe} / \mathrm{g}$ d.w. (95\% CI -15.1 to -6.0 ) for patients with MDS, $\mathrm{AA}$ and other rare anemias, respectively.

Among the 41 patients who had an LIC measurement in year 2 (PP2), the mean absolute change in LIC from baseline was consistent with year 1 (fig. $2 b$ ) overall [ -13.5 $\pm 14.1 \mathrm{mg} \mathrm{Fe} / \mathrm{g}$ d.w. (95\% CI -18.0 to -9.1 ), mean relative change $-47.9 \%$ ], for MDS [-11.5 $\pm 14.3 \mathrm{mg} \mathrm{Fe} / \mathrm{g} \mathrm{d}$.w. (95\% CI -19.1 to -3.9$)]$ and for patients with other rare anemias [-11.0 $\pm 11.6 \mathrm{mg} \mathrm{Fe} / \mathrm{g}$ d.w. (95\% CI -17.4 to -4.6$)]$. Patients with AA had a considerably greater reduction [-20.6 $\pm 16.2 \mathrm{mg} \mathrm{Fe} / \mathrm{g}$ d.w. (95\% CI -32.2 to -9.0$)]$. At year 2 , the greatest reduction in LIC was observed in patients with the highest baseline iron levels (LIC $\geq 15 \mathrm{mg} \mathrm{Fe} / \mathrm{g}$ d.w.; table 2). Efficacy in both the PP1 and PP2 patient sets was confirmed by sensitivity analyses based on the safety set, with mean absolute change in LIC of -10.5 and -12.0 $\mathrm{mg} \mathrm{Fe} / \mathrm{g} \mathrm{d}$.w. at the end of year 1 and year 2, respectively. 
Fig. 2. Mean change in LIC and after 1 year (a) and 2 years (b) of treatment, by underlying anemia, in Japanese and non-Japanese patients.

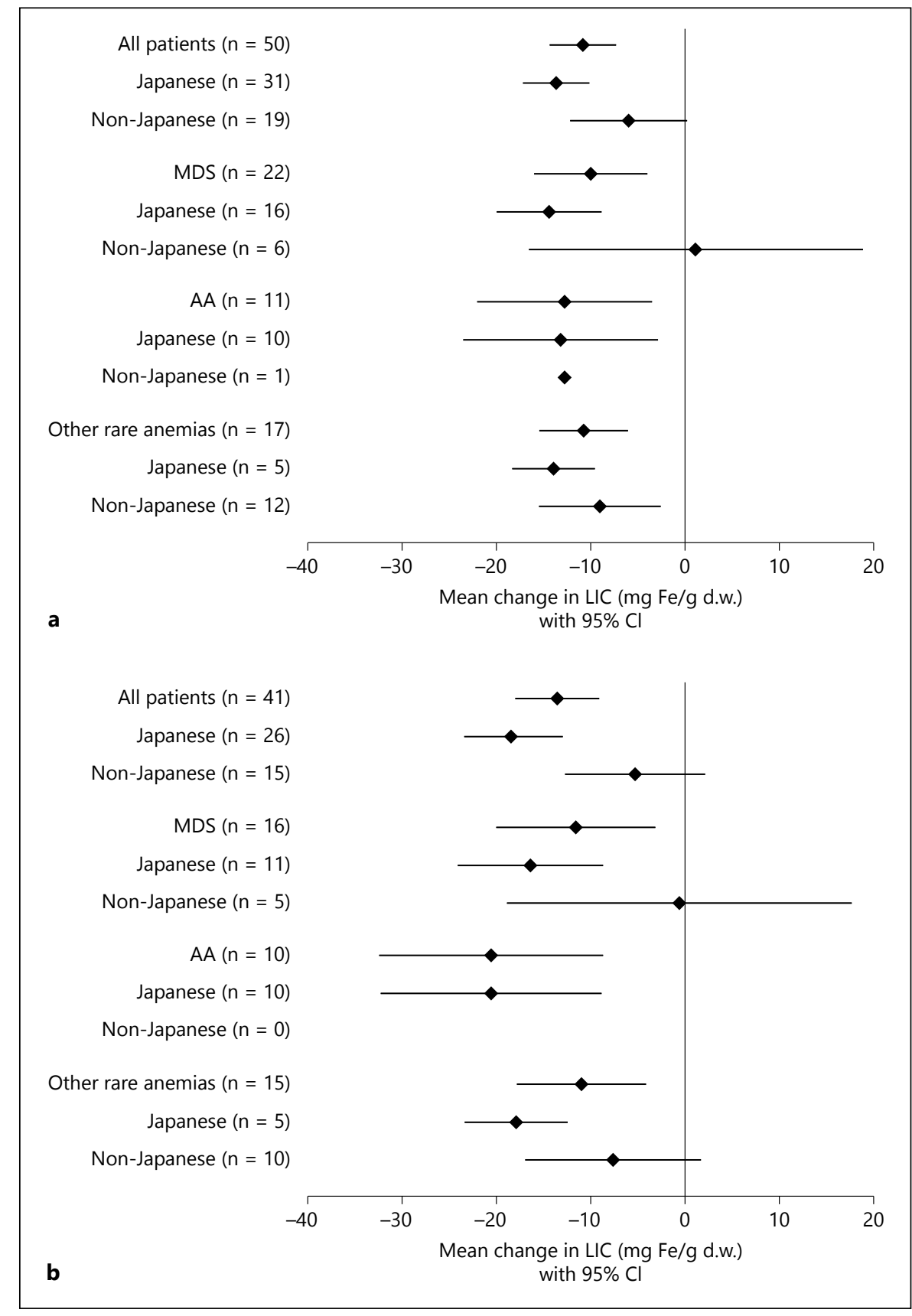

Table 2. Mean absolute change in LIC after 2 years of treatment by baseline LIC category

\begin{tabular}{lrlcc}
\hline $\begin{array}{l}\text { Baseline LIC category, } \\
\text { mg Fe/g d.w. }\end{array}$ & $\mathrm{n}$ & \multicolumn{2}{l}{ Mean LIC (SD), mg Fe/g d.w. } \\
\cline { 4 - 5 } & & baseline & end of extension & absolute change \\
\hline All patients & 41 & $23.1(15.7)$ & $9.5(11.4)$ & $-13.5(14.1)$ \\
$\quad<7$ & 4 & $4.1(2.4)$ & $3.7(2.8)$ & $-0.4(1.7)$ \\
$\geq 7$ to $<15$ & 12 & $10.0(1.9)$ & $6.5(4.1)$ & $-3.5(5.4)$ \\
$\geq 15$ & 25 & $32.4(13.1)$ & $11.9(13.8)$ & $-20.5(13.7)$ \\
\hline
\end{tabular}


Table 3. Median change in serum ferritin at 1 and 2 years

\begin{tabular}{|c|c|c|c|c|c|c|c|c|}
\hline \multirow{2}{*}{$\begin{array}{l}\text { Median serum } \\
\text { ferritin level, } \\
\mathrm{ng} / \mathrm{ml}\end{array}$} & \multicolumn{2}{|l|}{ MDS } & \multicolumn{2}{|l|}{ AA } & \multicolumn{2}{|c|}{ Other rare anemias } & \multicolumn{2}{|l|}{ All patients } \\
\hline & $\begin{array}{l}\text { year } 1 \\
(n=22)\end{array}$ & $\begin{array}{l}\text { year } 2 \\
(\mathrm{n}=16)\end{array}$ & $\begin{array}{l}\text { year } 1 \\
(\mathrm{n}=11)\end{array}$ & $\begin{array}{l}\text { year } 2 \\
(\mathrm{n}=10)\end{array}$ & $\begin{array}{l}\text { year } 1 \\
(\mathrm{n}=17)\end{array}$ & $\begin{array}{l}\text { year } 2 \\
(\mathrm{n}=15)\end{array}$ & $\begin{array}{l}\text { year } 1 \\
(n=50)\end{array}$ & $\begin{array}{l}\text { year } 2 \\
(n=41)\end{array}$ \\
\hline At baseline & 3,215 & 2,890 & 3,370 & 3,285 & 2,218 & 1,969 & 2,775 & 2,438 \\
\hline Range & 538 to 12,360 & 538 to 12,360 & 1,830 to 27,550 & 1,550 to 27,550 & 110 to 7,190 & 110 to 7,190 & 110 to 27,550 & 110 to 27,550 \\
\hline At the study end & 1,750 & 1,600 & 2,300 & 1,220 & 1,185 & 680 & 1,690 & 1,157 \\
\hline Range & $-5,260$ to 1,124 & $-9,040$ to 1,115 & $-11,150$ to 1,770 & $-17,250$ to 3,810 & $-2,767$ to 197 & $-2,860$ to 448 & $-11,150$ to 1,770 & $-17,250$ to 3,810 \\
\hline
\end{tabular}

PP1 was performed after year 1 and PP2 was performed after year 2 .

Changes in Serum Ferritin

Serum ferritin decreased by a median of $922 \mathrm{ng} / \mathrm{ml}$ (range $-11,150$ to $1,770 \mathrm{ng} / \mathrm{ml}$ ) after 1 year of deferasirox treatment and $1,198 \mathrm{ng} / \mathrm{ml}(-17,250$ to $3,810 \mathrm{ng} / \mathrm{ml})$ after 2 years (table 3 ). The highest median percentage change in serum ferritin $(-49 \%)$ was observed in AA patients after 1 year, although this group had the fewest patients $(n=11)$ and the largest baseline range.

Efficacy of Deferasirox in Japanese Patients

The median age of the MDS patients was 66.5 years for the Japanese patients versus 67.5 years for the nonJapanese patients. Non-Japanese patients had a substantially lower median age (22.0 and 11.0 years, respectively) than Japanese patients (57.0 and 40.0 years, respectively) in the groups with AA and other rare anemias. Mean baseline LIC was higher in patients with AA $(29.2 \pm 15.8 \mathrm{mg}$ $\mathrm{Fe} / \mathrm{g}$ d.w.) than in those with MDS $(27.7 \pm 17.5 \mathrm{mg} \mathrm{Fe} / \mathrm{g}$ d.w.) and those with other rare anemias $(27.0 \pm 14.2 \mathrm{mg}$ Fe/g d.w.). Median serum ferritin levels were 3,665, 3,385 and $2,740 \mathrm{ng} / \mathrm{ml}$ in AA, MDS and other rare anemia patients, respectively. The mean actual deferasirox dose was $15.7 \pm 5.40 \mathrm{mg} / \mathrm{kg} /$ day, compared with $20.0 \pm 6.69 \mathrm{mg} / \mathrm{kg} /$ day for non-Japanese patients. The median duration of exposure was 96.4 weeks for Japanese patients $(n=53)$ and 81.3 weeks for non-Japanese patients $(n=49)$.

Among the 31 Japanese patients, the mean absolute change in LIC was $-13.9 \mathrm{mg} \mathrm{Fe} / \mathrm{g}$ d.w. (95\% CI -17.6 to $-10.2)$ after 1 year of deferasirox treatment and $-18.4 \mathrm{mg}$ $\mathrm{Fe} / \mathrm{g}$ d.w. (95\% CI -23.4 to -13.3 ) in the 26 remaining patients after 2 years of treatment (fig. 2). The decrease was slightly greater in magnitude than observed for the overall population ( $-10.9 \mathrm{mg} \mathrm{Fe} / \mathrm{g} \mathrm{d}$.w.). The median absolute decrease in serum ferritin after 1 year $(-1,600$ $\mathrm{ng} / \mathrm{ml}$, range: -11 to $150-1,770)$ was higher than for
non-Japanese patients $(-427 \mathrm{ng} / \mathrm{ml}$, range: $-2,767$ to 1,123). A similar trend observed at the end of 2 years showed the median absolute change was $-1,952 \mathrm{ng} / \mathrm{ml}$ $(-17,250$ to $3,810 \mathrm{ng} / \mathrm{ml})$ and $-155 \mathrm{ng} / \mathrm{ml}(-1,717$ to 1,115 $\mathrm{ng} / \mathrm{ml})$, respectively. Of note, median baseline serum ferritin levels were higher in Japanese patients $(3,370 \mathrm{ng} / \mathrm{ml}$, range: 538-27,550) compared with non-Japanese patients $(2,241 \mathrm{ng} / \mathrm{ml}$, range: $110-8,171)$.

\section{Safety Parameters}

\section{Adverse Events}

Regardless of causality, AEs were observed in 97 (95.1\%) of the 102 patients overall. The most common were pyrexia $(\mathrm{n}=31,30.4 \%)$ and nasopharyngitis $(\mathrm{n}=30$, $29.4 \%$ ), and were more common in patients with MDS and AA than in patients with other rare anemias.

AEs with a suspected relationship to the study drug were reported in 65 patients (63.7\%; table 4$)$. A lower incidence of AEs (32.3\%) was observed in patients with other rare anemias than in MDS (83.3\%) and AA patients (69.0\%). The most frequent AE related to the study drug was increased serum creatinine $(23.5 \%)$, with the highest incidence in patients with MDS. SAEs were reported in $45.1 \%$ patients (table 4 ). Of these, $9.8 \%$ had a suspected relationship to the study drug and were comparable between anemias. Pyrexia and hypersensitivity were the most frequently reported, with 2 cases in each, i.e. MDS $4.8 \%$ and AA $6.9 \%$. No other SAEs were reported in more than 1 patient. One patient (3.2\%) in the 'other rare anemia' group presented with a moderate cataract.

Overall, 14 patients died during the study. Ten deaths occurred between the start of the study drug and 28 days after the last dose, 3 occurred $>28$ days after the last dose and 1 occurred at an unknown date (on or after day 28 after the last dose). Twelve of the patients who died were 
Table 4. Incidence of AEs by underlying anemias (safety set)

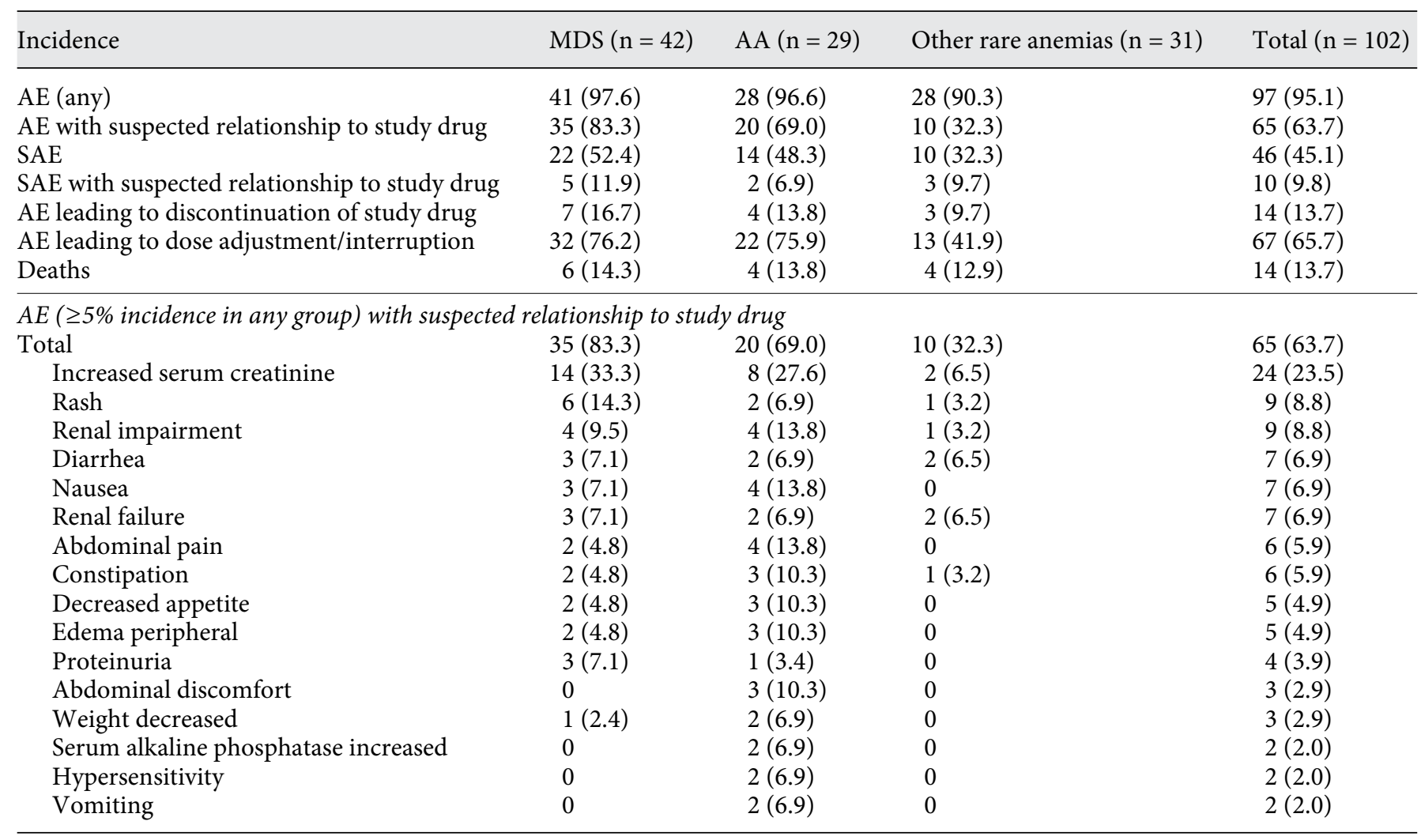

Values denote $\mathrm{n}(\%)$. A patient may appear more than once in each column because more than one type of event may have occurred.

older patients ( $\geq 55$ years) and 10 were Japanese. One death, which occurred as a result of pneumonia in a 70-year-old female Japanese patient with MDS, was suspected by the investigator to be related to the study drug. The remaining 13 were considered to not be related to the study drug; 5 occurred in patients with MDS [due to a deterioration in their general health $(\mathrm{n}=2$, and 1 also experienced marasmus), cardiac failure, disseminated intravascular coagulation and septic shock $(n=1)$, a gastrointestinal ulcer $(\mathrm{n}=1)$ or disease progression $(\mathrm{n}=1)], 4$ occurred in patients with AA [cerebellar hemorrhage $(\mathrm{n}=1)$, disseminated intravascular coagulation $(\mathrm{n}=1)$, traumatic hemorrhage $(\mathrm{n}=1)$ or AA and pneumonia $(\mathrm{n}=$ 1)] and 4 occurred in patients with other rare anemias [progression of myelofibrosis $(\mathrm{n}=2)$, systemic fungal infection $(n=1)$ or no specific cause $(n=1)]$.

\section{Ophthalmic Assessment}

At year 2, long-term ocular data were available for 50 patients. By clinical assessment, significant abnormal results were reported in 10 patients (20.0\%). Eight of these had clinically significant abnormalities at baseline, 1 was normal at baseline and 1 had no baseline assessment. Four patients with abnormal ocular findings had a suspected relationship to the study drug; 3 had cataracts and 1 had a retinal hemorrhage with lenticular opacities. Three patients were older than 60 years.

\section{Laboratory Abnormalities}

Increases in aspartate aminotransferase $>5$ times ULN and $>2$ times baseline value occurred in 2 patients, i.e. in $1 / 42$ patients with MDS (2.4\%) and in $1 / 31$ patients with other rare anemias (3.2\%). Alanine aminotransferase $>5$ times ULN and $>2$ times baseline value occurred in 6 patients, i.e. in $3 / 42$ patients with MDS (7.1\%) and in $3 / 31$ patients with other rare anemias $(9.7 \%)$. There were no differences in hepatic parameters between the underlying anemias.

Two consecutive serum creatinine increases $>$ ULN and $>33 \%$ from baseline occurred in 37 patients (36.3\%); there were more in the MDS $(\mathrm{n}=17)$ and AA patients $(\mathrm{n}=15)$ than in the group with other rare anemias $(\mathrm{n}=$ 
5). Of these 37 patients, the median age was 65 years (vs. 44 years for the other patients in the safety set). Of 19 patients treated with concomitant calcineurin inhibitors (ophthalmic cyclosporine or tacrolimus), 13 (68.4\%) had notable increases in serum creatinine compared with 24 of the remaining 83 patients (28.9\%) who did not receive calcineurin inhibitors. Increases were managed with dose reductions and/or interruption in most cases, although serum creatinine remained elevated $>\mathrm{ULN}$ and $>33 \%$ from baseline in 14 patients at the last available assessment.

\section{Safety of Deferasirox in Japanese Patients}

Over 2 years of deferasirox treatment, safety parameters in Japanese patients were generally comparable to the overall population. However, 10/14 of the deaths were Japanese patients; 9 of these occurred in patients who were $\geq 55$ years old.

\section{Discussion}

Effective management of iron overload in transfusiondependent patients with anemias such as MDS or AA has been shown to improve time to progression of the disease and overall patient survival $[4,5,7,9,10,12,22]$. This study provides additional long-term data on efficacy and safety for tailored deferasirox therapy in patients with MDS, AA or other rare anemias, and includes the assessment of a large population of Japanese patients. The findings show clinically relevant reductions in body iron burden as assessed by both LIC and serum ferritin, based on an adjusted dosing strategy considering transfusional iron intake, treatment goals, therapeutic response and safety assessments; as such, most patients received dose adjustments (88.2\%). A large proportion of patients had severe liver iron overload at baseline (mean \pm SD LIC $24.5 \pm 15.6 \mathrm{mg} \mathrm{Fe} / \mathrm{g}$ d.w.), which decreased by $10.9 \pm 11.9$ $\mathrm{mg} \mathrm{Fe} / \mathrm{g}$ d.w. after 1 year of deferasirox therapy (95\% CI -14.3 to $-7.5 ; \mathrm{p}<0.001)$ and by $13.5 \pm 14.1 \mathrm{mg} \mathrm{Fe} / \mathrm{g}$ d.w. after 2 years (95\% CI -18.0 to -9.1$)$ with an average deferasirox dose of $17.8 \pm 6.4 \mathrm{mg} / \mathrm{kg} /$ day. Clinically relevant reductions in serum ferritin were also observed over this time course.

In this study, LIC was assessed by means of MRI. Although serum ferritin is commonly used as an indirect measure of LIC, it has recently been demonstrated that patients with MDS may have severely elevated LIC despite only moderately elevated serum ferritin levels [32]. This indicates that, in these patients, iron accumulates more rapidly than was previously assumed. Overall, changes in both LIC and serum ferritin were generally consistent with the results of earlier studies, including those from the MDS and AA subpopulations of the EPIC study [13, 15, 20-27]. In our study, baseline LIC and serum ferritin levels were lower in patients with other rare anemias than in those with MDS and AA, but changes in both parameters were similar in all 3 groups. Changes in LIC following 2 years of treatment were more variable than at 1 year as a result of the smaller number of patients. They nevertheless confirmed the 1-year results, showing a clinically significant, absolute change in LIC overall.

Deferasirox was generally well-tolerated with no unexpected toxicities and the safety profile was consistent with that observed in previous studies on patients with a variety of underlying conditions [13-21, 23, 24, 26, 27]. AEs in general and those with a suspected relationship to the study drug were more frequent in patients with MDS or AA than in patients with other rare anemias. Possible explanations for this include: the greater age of patients with MDS, i.e. 63.6 years vs. 48.9 years (AA) and 25.4 years (other rare anemias), the neoplastic nature of the disease and more rapid deterioration than with other nonmalignant disorders and the impact of preexisting comorbidities and concomitant medications. These explanations are considered the reason for the higher discontinuations due to AEs previously reported in MDS patients compared with patients with thalassemia or SCD [13]. Furthermore, the rates of drug-related AEs and SAEs in patients with MDS and AA from our study appeared to be higher than previously observed in the EPIC study [13, 18,24 , with a higher frequency of increases in serum creatinine being reported. The reasons for this are not clear, but it may have been due to the heterogeneity of patient populations as a result of underlying conditions and ongoing therapies (other than iron chelation therapy).

The most common investigator-reported drug-related $\mathrm{AE}$ reported was increased serum creatinine. Incidences were higher in the MDS group than in patients with AA and other rare anemias, which could have been due to the older age and general susceptibility to renal changes in the MDS patients. Furthermore, approximately two thirds of the patients who received concomitant ophthalmic calcineurin inhibitors, which are known to contribute to renal dysfunction [33], experienced notable increases in serum creatinine. Renal function in patients receiving deferasirox and concomitant calcineurin should therefore be closely monitored. Other studies have also demonstrated deferasirox dose-dependent serum creatinine increases, although these are usually within normal limits, and 
nonprogressive and reversible with dose reduction and/ or interruption [14-19, 24]. Only 1 of the 14 deaths reported was suspected to be related to the study drug and it was reported in the posttreatment period (the principal cause of death was pneumonia). Ophthalmological data over 2 years remained generally consistent with the values observed at baseline. Although 4 patients were reported to have ophthalmologic AEs that were suspected by the investigator to be related to the study drug, these generally occurred in older patients, and such conditions are usually associated with increased age [34].

Of the 102 patients, more than half were Japanese, mostly in the AA or MDS subpopulations, with variations in mean age across their underlying anemias. Despite some differences in baseline characteristics, the results demonstrate that changes in the primary efficacy end points for Japanese patients were consistent with the overall population. The overall safety profile was also generally consistent between Japanese and non-Japanese patients, but there were more deaths in the Japanese subgroup (10/14 deaths overall occurred in Japanese patients); this may be related to the higher number of Japanese patients $(26 / 53,49 \%)$ than non-Japanese MDS patients $(n=16 / 49,33 \%)$ in the MDS population. In addition, the median age of patients with AA or other rare anemias was higher in Japanese than in non-Japanese patients, and deaths occurred largely in older patients, many of whom suffered from leukopenia (absolute neutropenia), with febrile neutropenia and/or sepsis or systemic infections or other disease complications. As such, most deaths were not attributed to iron chelation therapy, but to systemic disorders or complications associated with an underlying disease.

In summary, the efficacy and safety of deferasirox in this study over a 1-year and 2-year treatment period were consistent with previous studies on patients with MDS, $\mathrm{AA}$ and other rare anemias. In order to optimize clinical outcomes, iron chelation treatment, including dose optimization, should be tailored according to individual patient requirements. The prospective results presented here indicate that deferasirox is an effective and well-tolerated oral iron chelator for the treatment of transfusiondependent, iron-overloaded patients with MDS, AA and other rare anemias. These findings will further contribute to understanding and updating guidelines for the management of iron overload and tailoring treatment. They are therefore valuable for informing physicians regarding treatment decisions.

\section{Acknowledgements}

The study was sponsored by Novartis Pharma AG and designed by the sponsor in close collaboration with the Study Steering Committee. We thank Bethan Hahn of Mudskipper Business, Ltd., for medical editorial assistance. Financial support for medical editorial assistance was provided by Novartis Pharmaceuticals.

\section{Disclosure Statement}

Y.K. reports participation in speaker's bureau and receiving research funding from Novartis Pharmaceuticals, Chugai Pharma, Tanabe-Mitsubishi Pharma, Takeda Pharma, Ajinomoto Pharma, and Nisshin-Kyorin Pharma; and research funding from Asahikasei Medical and Sapporo Beer. W.W.-J. reports receiving honoraria and research funding from Novartis Pharmaceuticals, Roche and Celgene; and honoraria from Jansen-Cilag, Amgen and Onconova. S.G. is an employee of Novartis Pharma CW is an employee of Novartis Pharmaceuticals. A.U., Y.K., L.A., K.W., K.M. and L.C.L. have no relevant conflicts of interest to disclose.

\section{References}

1 Lipton JM, Atsidaftos E, Zyskind I, Vlachos A: Improving clinical care and elucidating the pathophysiology of Diamond Blackfan anemia: an update from the Diamond Blackfan Anemia Registry. Pediatr Blood Cancer 2006; 46:558-564.

2 Kurtin SE: Myelodysplastic syndromes: diagnosis, treatment planning, and clinical management. Oncology (Williston Park) 2007;21: 41-48.

3 Marsh JC, Ball SE, Cavenagh J, Darbyshire P, Dokal I, Gordon-Smith EC, Keidan J, Laurie A, Martin A, Mercieca J, Killick SB, Stewart R, Yin JA: Guidelines for the diagnosis and management of aplastic anaemia. Br J Haematol 2009;147:43-70.

Deferasirox for MDS, AA and

Rare Anemias
4 Malcovati L, Della Porta MG, Pascutto C, Invernizzi $\mathrm{R}$, Boni $\mathrm{M}$, Travaglino E, Passamonti F, Arcaini L, Maffioli M, Bernasconi P, Lazzarino M, Cazzola M: Prognostic factors and life expectancy in myelodysplastic syndromes classified according to WHO criteria: a basis for clinical decision making. J Clin Oncol 2005;23:7594-7603.

5 Malcovati L: Impact of transfusion dependency and secondary iron overload on the survival of patients with myelodysplastic syndromes. Leuk Res 2007;31(suppl 3):S2-S6.

6 Roggero S, Quarello P, Vinciguerra T, Longo F, Piga A, Ramenghi U: Severe iron overload in Blackfan-Diamond anemia: a case-control study. Am J Hematol 2009;84:729-732.
7 Lyons RM, Marek BJ, Paley CS, Esposito J, McNamara K, Garbo L, DiBella N, Garcia-Manero G: 48-month update on survival and AML transformation in a 600-patient registry of lower-risk MDS patients. Blood 2013;122:2775.

8 Leitch HA: Controversies surrounding iron chelation therapy for MDS. Blood Rev 2011; 25:17-31.

9 Rose C, Brechignac S, Vassilief D, Pascal L, Stamatoullas A, Guerci-Bresler A, Larbaa D, Dreyfus F, Beyne-Rauzy O, Chaury MP, Roy L, Cheze S, Morel P, Fenaux P: Does iron chelation therapy improve survival in regularly transfused lower risk MDS patients? A multicenter study by the GFM. Leuk Res 2010;34: 864-870. 
10 Neukirchen J, Fox F, Kundgen A, Nachtkamp K, Strupp C, Haas R, Germing U, Gattermann $\mathrm{N}$ : Improved survival in MDS patients receiving iron chelation therapy - a matched pair analysis of 188 patients from the Dusseldorf MDS registry. Leuk Res 2012;36:1067-1070.

11 Lyons R, Marek BL, Sharma S, Paley C, Esposito J, Garbo L, DiBella N, Garcia-Manero G: 24-Month analysis of the impact of chelation on clinical outcomes in a 600 patient registry of lower-risk MDS patients. Blood 2011; 118:2800.

12 Neukirchen J, Germing U, Fox F, Glaser S, Gattermann N: The impact of iron chelation therapy on clinical outcomes in real-world lower-risk patients with myelodysplastic syndromes (MDS): results from the Düsseldorf registry. Haematologica 2012;97(suppl 1): 359.

13 Gattermann N, Finelli C, Della Porta M, Fenaux P, Ganser A, Guerci-Bresler A, Schmid M, Taylor K, Vassilief D, Habr D, Domokos G, Roubert B, Rose C: Deferasirox in ironoverloaded patients with transfusion-dependent myelodysplastic syndromes: results from the large 1-year EPIC study. Leuk Res 2010; 34:1143-1150.

14 Cappellini MD, Cohen A, Piga A, Bejaoui M, Perrotta S, Agaoglu L, Aydinok Y, Kattamis A, Kilinc Y, Porter J, Capra M, Galanello R, Fattoum S, Drelichman G, Magnano C, Verissimo M, Athanassiou-Metaxa M, Giardina B, Kourakli-Symeonidis A, Janka-Schaub G, Coates T, Vermylen C, Olivieri N, Thuret I, Opitz H, Ressayre-Djaffer C, Marks P, Alberti D: A phase 3 study of deferasirox (ICL670), a once-daily oral iron chelator, in patients with beta-thalassemia. Blood 2006; 107:34553462.

15 Porter J, Galanello R, Saglio G, Neufeld EJ, Vichinsky E, Cappellini MD, Olivieri N, Piga A, Cunningham MJ, Soulières D, Gattermann N, Tchernia G, Maertens J, Giardina P, Kwiatkowski J, Quarta G, Jeng M, Forni GL, Stadler M, Cario H, Debusscher L, Della Porta M., Cazzola M, Greenberg P, Alimena G, Rabault B, Gathmann I, Ford JM, Alberti D, Rose C: Relative response of patients with myelodysplastic syndromes and other transfusion-dependent anaemias to deferasirox (ICL670): a 1-year prospective study. Eur J Haematol 2008;80:168-176.

16 Vichinsky E, Onyekwere O, Porter J, Swerdlow P, Eckman J, Lane P, Files B, Hassell K, Kelly P, Wilson F, Bernaudin F, Forni GL, Okpala I, Ressayre-Djaffer C, Alberti D, Holland J, Marks P, Fung E, Fischer R, Mueller BU, Coates T: A randomized comparison of deferasirox versus deferoxamine for the treatment of transfusional iron overload in sickle cell disease. Br J Haematol 2007; 136:501-508.

17 Cappellini MD, Taher A: Long-term experience with deferasirox (ICL670), a once-daily oral iron chelator, in the treatment of transfusional iron overload. Expert Opin Pharmacother 2008;9:2391-2402.

18 Cappellini MD, Porter JB, El-Beshlawy A, Li C-K, Seymour JF, Elalfy M, Gattermann N, Giraudier S, Lee J-W, Chan LL, Lin K-H, Rose C, Taher A, Thein SL, Viprakasit V, Habr D, Domokos G, Roubert B, Kattamis A; EPIC Study Investigators: Tailoring iron chelation by iron intake and serum ferritin trends: the prospective multicenter EPIC study of deferasirox in 1744 patients with various transfusion-dependent anemias. Haematologica 2010;95:557-566.

19 Taher AT, Porter JB, Viprakasit V, Kattamis A, Chuncharunee S, Sutcharitchan P, Siritanaratkul N, Galanello R, Karakas Z, Lawniczek T, Habr D, Ros J, Zhu Z, Cappellini MD: Deferasirox effectively reduces iron overload in non-transfusion-dependent thalassemia (NTDT) patients: 1-year extension results from the THALASSA study. Ann Hematol 2013;92:1485-1493.

20 Angelucci E, Santini V, Di Tucci AA, Quaresmini G, Finelli C, Volpe A, Quarta G, Rivellini F, Sanpaolo G, Cilloni D, Salvi F, Caocci G, Molteni A, Vallisa D, Voso MT, Fenu S, Borin L, Latte G, Alimena G, Storti S, Piciocchi A, Fazi P, Vignetti M, Tura S: Deferasirox for transfusion-dependent patients with myelodysplastic syndromes: safety, efficacy, and beyond (GIMEMA MDS0306 Trial). Eur J Haematol 2014;92:527-536.

21 Cheong JW, Kim HJ, Lee KH, Yoon SS, Lee JH, Park HS, Kim HY, Shim H, Seong CM, Kim CS, Chung J, Hyun MS, Jo DY, Jung CW, Sohn SK, Yoon HJ, Kim BS, Joo YD, Park CY, Min YH: Deferasirox improves hematologic and hepatic function with effective reduction of serum ferritin and liver iron concentration in transfusional iron overload patients with myelodysplastic syndrome or aplastic anemia. Transfusion 2014;54:1542-1551.

22 Delforge M, Selleslag D, Beguin Y, Triffet A, Mineur P, Theunissen K, Graux C, Trullemans F, Boulet D, Van EK, Noens L, Van SS, Lemmens J, Pierre P, d'Hondt R, Ferrant A, Deeren D, Van D, V, Wynendaele W, Andre M, De BR, Efira A, Breems D, Deweweire A, Geldhof K, Pluymers W, Harrington A, Macdonald K, Abraham I, Ravoet C: Adequate iron chelation therapy for at least six months improves survival in transfusion-dependent patients with lower risk myelodysplastic syndromes. Leuk Res 2014;38:557-563.

23 Greenberg PL, Koller CA, Cabantchik ZI, Warsi G, Glynos T, Paley C, Schiffer C: Prospective assessment of effects on iron-overload parameters of deferasirox therapy in patients with myelodysplastic syndromes. Leuk Res 2010;34:1560-1565.

24 Lee J-W, Yoon S-S, Shen ZX, Ganser A, Hsu H-C, Habr D, Domokos G, Roubert B, Porter
JB: Iron chelation therapy with deferasirox in patients with aplastic anemia: a subgroup analysis of 116 patients from the EPIC trial. Blood 2010;116:2448-2454.

25 Lee JW, Yoon SS, Shen ZX, Ganser A, Hsu HC, El-Ali A, Habr D, Martin N, Porter JB: Hematologic responses in patients with aplastic anemia treated with deferasirox: a post hoc analysis from the EPIC study. Haematologica 2013;98:1045-1048.

26 List AF, Baer MR, Steensma DP, Raza A, Esposito J, Martinez-Lopez N, Paley C, Feigert J, Besa E: Deferasirox reduces serum ferritin and labile plasma iron in RBC transfusiondependent patients with myelodysplastic syndrome. J Clin Oncol 2012;30:2134-2139.

27 Nolte F, Hochsmann B, Giagounidis A, Lubbert M, Platzbecker U, Haase D, Luck A, Gattermann N, Taupitz M, Baier M, Leismann O, Junkes A, Schumann C, Hofmann WK, Schrezenmeier H: Results from a 1-year, open-label, single arm, multi-center trial evaluating the efficacy and safety of oral Deferasirox in patients diagnosed with low and int-1 risk myelodysplastic syndrome (MDS) and transfusion-dependent iron overload. Ann Hematol 2013;92:191-198.

28 Suzuki T, Tomonaga M, Miyazaki Y, Nakao S, Ohyashiki K, Matsumura I, Kohgo Y, Niitsu Y, Kojima S, Ozawa K: Japanese epidemiological survey with consensus statement on Japanese guidelines for treatment of iron overload in bone marrow failure syndromes. Int J Hematol 2008;88:30-35.

29 Takatoku M, Uchiyama T, Okamoto S, Kanakura Y, Sawada K, Tomonaga M, Nakao S, Nakahata T, Harada M, Murate T, Ozawa K: Retrospective nationwide survey of Japanese patients with transfusion-dependent MDS and aplastic anemia highlights the negative impact of iron overload on morbidity/mortality. Eur J Haematol 2007;78:487-494.

30 Novartis Pharmaceuticals: EXJADE ${ }^{\circledR}$ (deferasirox) US prescribing information, 2013. http://www.pharma.us.novartis.com/ product/pi/pdf/exjade.pdf.

31 St Pierre TG, Clark PR, Chua-anusorn W, Fleming AJ, Jeffrey GP, Olynyk JK, Pootrakul $\mathrm{P}$, Robins E, Lindeman R: Noninvasive measurement and imaging of liver iron concentrations using proton magnetic resonance. Blood 2005; 105:855-861.

32 Gattermann N, Greenberg P, Urabe A, El-Ali A, Martin N, Porter J: Estimation of the relationship between serum ferritin and liver iron concentration in patients with myelodysplastic syndromes. Haematologica 2013; 98(suppl 1):abst P419.

33 Mason J: The effect of cyclosporin on renal function. J Autoimmun 1992;5(suppl A):349_ 354.

34 Voleti VB, Hubschman JP: Age-related eye disease. Maturitas 2013;75:29-33. 